\title{
파키스탄 개발포럼 개최 결과
}

주요 원조공여국 외교단 및 정부대표, $\mathrm{ADB}$ 등 국 제기구대표 및 NGO 등이 참석한 가운데 2005년 4 월 25 26일 파키스탄 정부 주관으로 파키스탄 개발 포럼(PDF)이 파키스탄에서 개최되었는 바, 포럼의 주요 내용은 다음과 같음.

\section{I . 핵심요지}

Shaukat Aziz 총리는 기조연설을 통해

- 국민총생산 $6.5 \%$ 성장 달성, 해외직접투자증대, 외환보유고 안정 등 각 부문에서 경제상황이 호전되 고 있음을 설명하면서

-파키스탄에 대한 국제이미지 개선 노력강화, 각 종 규제완화를 통한 외국인 투자환경 개선, 주요 국 · 공영 기업민영화 지속, 금융 및 조세제도 개 혁을 통한 투명성 제고, 에너지개발 국제협력 강 화정책 등을 통해 7 8\%대의 경제성장을 달
성 · 유지한다는 경제정책 방향을 제시하였으며 -이를 위해 수자원 확보, 에너지 안보, 인프라개 발, 인적자원개발이 최우선과제임을 강조, 각국 원조공여국 및 국제기구 등의 지속적인 지원을 요청함

ㅁ 포럼에 참석한 $\mathrm{WB}, \mathrm{ADB}, \mathrm{IMF}$ 등 국제기구는 최근 3 4년간 파키스탄의 경제여건이 지속적으로 개선 되고 있다고 평가, 향후 파키스탄의 정치 - 안보 상 황이 안정될 경우 7 8\% 이상의 경제성장 달성이 가능하다고 예측하면서 도로, 댐, 에너지분야 인프 라 개발 지원 필요성을 강조하고 파키스탄 정부에 행정 효율성 및 투명성 제고 노력을 촉구함.

\section{II. 주요내용}

1. 전체회의(개막식)

ㅁ $\mathrm{ADB}$ 는 2005 회계년도 $6.6 \%$ 경제성장을 전망하 
고 향후 5 년 내에 $8 \%$ 대 성장 가능성을 예측하면서 경제개혁 지속이 관건이며 경제성장 성과가 빈곤 층 및 지방에 확산되도록 하는 정책이 긴요함을 강 조함

WB는 금년도 $7 \%$ 경제성장 가능성을 예측하면서 경제성장 과실이 빈곤층, 사회적 약자 및 지방에 침투되도록 하는 노력이 요망되며 21세기에 대비 한 인프라 개발, 노동시장 육성, 조세행정 개선, 지 방개발 확충 등의 분야에 대한 배려가 필요함을 강 조함.

ㅁ IMF는 파키스탄이 2004년도에 IMF 체제를 졸업 한 점 등 괄목할만한 경제성장을 달성했으나 $\mathrm{IMF}$ 졸업 이후 물가상승 압력, 주식시장의 불확실성 등 불안요인에 대한 관리문제가 남아있음을 지적하고 민간여신 확대 등 은행분야 개혁 필요성을 강조함.

\section{2. 빈곤퇴치 및 고용창출}

ㅁ EU는 파키스탄 정부가 추진 중인 각 분야별 '천년 개발목표(Millenium Development Goals : $\mathrm{MDG})^{\prime}$ 가 양성간, 지역간, 계층간 불평등 해소에 대한 구체적인 방안이 부재하며 경제성장 자체가 절대빈곤층 해소를 보장하는 것이 아님을 지적하 면서 이에 대한 구체적인 정책방안 제시가 필요하 며 $\mathrm{MDG}$ 의 일환으로 추진하고 있는 중기개발계획 의 이행상황에 대한 모니터링 능력 배양을 위해 국 가 차원의 통계시스템 구축이 필요함을 지적함.

\section{3. 사회 인프라 개발 및 민영화}

ㅁ파키스탄 정부는 $\mathrm{MDG}$ 달성을 위해 수자원 관리,
도로, 항만, 에너지 개발 및 유통구조 개선에 필요 한 소요재원 등 인프라 개선 기본 구상을 제시하면 서 원조공여국의 지원을 강조함.

$-\mathrm{ADB}$ 는 파키스탄 정부의 각종 사회 인프라 프로 젝트에 대한 사후 평가와 관리부실로 막대한 투 자자원이 낭비되고 있는 사실을 지적하고 사후 관리 능력배양 지원 필요성을 강조함.

ㅁ파키스탄 정부는 통신, 건설, 전력, 에너지 분야 주 요 공기업 민영화가 착실히 진전되고 있으며 민영 화 추진과정에서 특정 외국기업에 대한 우대 문제 점 제기에 대해 향후 투명성 제고를 강화해 나간다 는 방침을 제시함.

\section{4. 고용 및 인적자원 개발}

ㅁ파키스탄 고등교육위원회(HEC)는 사회 · 경제 개 발을 위해 인적자원개발(HRD)이 기본 요건임을 강조하면서 기초교육 확대, 문맹퇴치 및 기술 - 직 업교육이 원활하게 이루어지기 위해서는 교수요 원 확보 및 교육시설 정비가 필수적인 바, $\mathrm{HRD}$ 분 야에 향후 2 3년간 약 700 억 루피(약 10 억불)의 재원이 필요하다고 설명함.

\section{5. 산업 · 통상 · 농업 정책}

ㅁㅍ키스탄 산업부는 제조업이 차지하는 비중이 지 난 20년간 20\%에 못 미치고 있으며 세계 수출시 장 점유율이 $0.18 \%$ 에 불과하다고 하면서 부진요 인으로 $10 \sim 15$ 년 주기의 정정불안 반복과 산업생 산 부진 사이클이 일치한다는 사실을 지적, 정치 안정의 중요성을 강조하면서 섬유, 기계, 중소기 
업 육성 등의 전략을 통해 2010년까지 제조산업 비중을 $25 \%$ 로 확대한다는 목표를 제시함.

ㅁ상무부는 수출 지역 및 품목 다양화를 통한 수출확 대와 수출환경 개선 등 두 가지 전략을 제시하면서 수출환경 개선을 위해 원자재 수입 등에 대한 최고 관세율을 $25 \%$ 까지 완화하였으며 중국, 태국, 말레 이시아와의 FTA(또는 PTA) 추진, SAFTA 발효 노력 강화 등 국제적 차원의 수출환경 개선 방안을 발표함.

ㅁ 식량 - 농업부는 파키스탄의 농업부문이 GDP의 $25 \%$, 고용의 $49 \%$, 직 - 간접 포함시 전체 수출비 중의 $70 \%$ 를 차지하는 바, 높은 잠재력에도 불구하 고 $\mathrm{WTO}$ 위생검역(SPS)에 따른 규제 등이 수출증 대에 장애가 되고 있음을 지적하면서 품질, 위생관 리 능력 배양을 위한 원조지원을 요망함.

\section{III. 관찰}

마키스탄 정부는 금번 포럼을 통해 중기개발계획 및 $\mathrm{MDG}$ 이행을 위해 총 410 억불 규모의 재원이 소요됨을 강조하고 국제기구 및 주요 원조공여국 의 재정지원과 투자를 유인하는데 노력을 집중함.
ㅁ $\mathrm{WB}, \mathrm{ADB}, \mathrm{IMF}$ 등은 최근 $3 \sim 4$ 년간의 경제성장 성과를 평가하고 사회 인프라 개발, 에너지분야 개 발 지원 의사를 표명하고 파키스탄 정부에 대해 행 정 효율성 및 각종 프로젝트의 이행과 관련한 투명 성 확보를 요망함.

미국측 USAID 대표는 인적자원 개발이 사회경제 개발의 관건임을 강조하면서 기초교육 및 기술 직업교육에 개발의 우선 순위를 두어야 하며, 농업 분야 발전과 사회적 분배가 제대로 이루어지기 위 해서는 지방유력자(일종의 영주)의 대토지 소유관 행 등에 대한 개혁 필요성을 제기함.

- 미국대표는 또한 국제투자를 활성화하기 위해서 는 지적소유권 제도 등이 정비되어야 함을 강조 ㅁ일본은 4 월 30 일 5 월 1 일간 고이즈미 총리의 파 키스탄 방문에 대비하는 차원에서 학계, 원조기관 (JICA) 및 외무성 대표로 구성된 본부대표단을 포 럼에 파견하는 등 관심을 표명하였으며 98년 이후 중단된 엔차관 재개 등을 강조함.

ㅁ 네덜란드, 스위스 및 $\mathrm{EU}$ 등은 개발계획 자체도 중 요하지만 각종 지원이 원활히 이행되는지 여부에 대한 사후 평가와 관리가 중요하다는 점을 제기함.

[자료: 주파키스탄 대사관] 